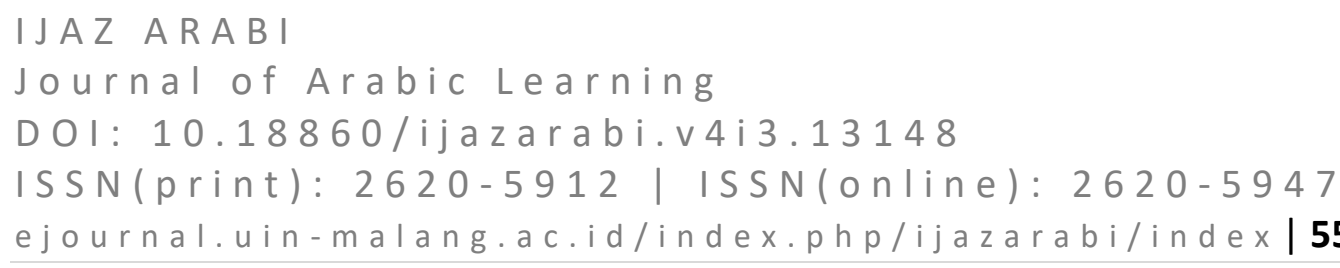

\title{
Video-Based Ice Breaker Game In The Department of Arabic Language Education
}

\author{
R. Taufiqurrochman', Hafiz Ahmed Saeed Rana' \\ Universitas Islam Negeri Maulana Malik Ibrahim Malang, Bahauddin Zakariya \\ University, Multan, Punjab, Pakistan ${ }^{2}$ \\ taufiq@uin-malang.ac.id ${ }^{1}$, hafizahmadsaeed90@gmail.com²
}

\begin{abstract}
Online and distance learning leads to reduced student motivation, boredom, and reduced levels of understanding. The solution to solve this problem is ice breakerbased video. In Arabic learning, ice breaker video content is not found much because ice breakers are usually practiced for offline learning. Therefore, ice breakers are required in videos for online learning by producing them in large quantities. This study aims to describe the results of a review of ice breaker-based videos that have been successfully designed by students in the Department of Arabic Language Education. It is a mixture of quantitative and qualitative approaches. With qualitative content analysis, it is known that students successfully produce Arabic-language ice breaker-based videos that are of good quality from the aspect of content, themes, and teaching materials for all levels of education, from children to adults. This video can be applied independently or under the guidance of a classroom teacher. The success of students in producing ice breaker-based videos is because the Arabic education curriculum has accommodated elective courses called Games, Songs, and Stories so that students are equipped with teaching skills and the ability to become content creators.
\end{abstract}

Keywords: Ice Breaker; Video; Arabic Learning

\section{INTRODUCTION}

Since the era of industrial revolution 4.0 rolling, the development of information and communication technology is increasing rapidly and touching into various fields, including education so that models of learning from offline to online, from classroom to remote, from manual to digital, and so forth (Rachmadtullah et al., 2020). This change is increasingly felt by many people during the Covid-19 pandemic which requires the learning process online, remotely, student-based and self-learning by utilizing technology products. Of course, this phenomenon causes positive and negative impacts.

The positive impacts include: various models of online and remote learning emerge, teachers and students are becoming more and more accustomed to the use of technological devices (Ariadhy, Nurohman, Arkum, Handini, \& Ferdiana, 2020), development of learning support applications is increasing, learning can take place anywhere and anytime, and so forth. While the negative impact that many felt from online learning in this pandemic era, among others: students' motivation is 
decreasing (Cahyani, Listiana, \& Larasati, 2020), students get bored to learn (Rifnida, Abdulloh, \& Helili, 2021), students' level of understanding of the lesson is decreasing (Puteri, Maharani, \& Wulandari, 2020), students' level of understanding of the lesson is decreasing (Fahruni \& Warsito, 2021), and inadequate facilities such as a slow internet network (Azzahra, 2020), don't have a computer or smartphone (Puteri et al., 2020), and so on.

These problems must be addressed and found solutions, especially related to the decrease in the level of motivation of students in learning. Because, if students' motivation decreases and interest in learning decreases, then students will be more unhappy in following online learning in this pandemic era, and this will result in lower student learning outcomes and failure. To solve this problem, one solution is the availability of ice breaker-based video which is an audio-visual medium. Ice breaker material designed in the form of video is part of the learning videos needed in the era of the Covid-19 pandemic. Given that almost all learning processes in the era of the Covid-19 pandemic require online, remotely and utilizing digital technology.

Heathfield (2020) stated that an icebreaker is an activity or game designed to welcome attendees and warm up the conversation among participants in a meeting, training class, team building session, or other activity. Any event that requires people to comfortably interact with each other and a facilitator is an opportunity to use an icebreaker. Ice breaker, according to Amalia (2020), able to restore the stamina of students so that the physical and psychic condition remains fresh and comfortable in receiving information and teaching materials delivered by the teacher. Thus, Ice breaker is a technique used in a training forum, seminar, meeting, or learning activity to solve the freeze or saturation that occurs in the forum so that the audience, students or participants are re-concentrated. If they are concentrated on speakers, trainers, or teachers, then it is expected that they will be aware of the material delivered so that they can more easily understand all the teaching materials.

The types of Ice breakers that can be used in learning are very diverse, including: games, singing, gestures, storytelling, audio visuals, brain games, words of wisdom, gymnastics, quizzes, puzzles, and applause. In online learning, ice breakers can be presented through electronic media with audio-visual or video lessons. Benefits of using videos to students: videos create a more engaging sensory experience than using print materials alone, they provide a go-to resource that can be watched from anywhere with an internet connection, videos increase knowledge retention, since they can be stopped and replayed as many times as needed, they greatly assist in the learning of all subjects, but particularly those topics that are complex and/or highly visual, such as step-by-step procedures, problem-solving, or science and math formulas, they increase proficiency in digital literacy and communication, which are important 21st-century skills (Bevan, 2020).

The implementation of ice breaker in Arabic language learning is still necessary due to several factors, among others: student conditions are diverse, student concentration is limited, there is saturation, monotonous learning, teacher 
and student communication is less interactive (Fadhal, 2020). In the era of Covid19 protesters, these factors are increasingly likely because the learning process takes place online and remotely.

Why is ice-breaker-based video an alternative and important solution for now? Because author see the results of previous studies have shown that ice breakers have a significant influence in improving motivation (Hutasoit \& Tambunan, 2018) (Devi, Muncarno, \& H, 2019) (Khoirullah, 2020), even ice breaker is able to improve students' learning outcomes (Solihat, Astuti, \& Satriani, 2020) (Putri, 2020) (Aziz, 2019).

Based on the facts of the study, the authors were encouraged to conduct research related to ice breaker-based video, especially for Arabic language learning. Because, previous research is not related to Arabic language learning, while ice breaker-based videos for Arabic language learning have not been studied, especially ice breaker videos designed directly by students who are learning Arabic because they are future Arabic teachers who are certainly required to be more creative, innovative, and master technology, including being able to design interactive learning videos containing ice breaker materials. This article describes the results of research that have not been found in previous studies.

In this article, the author intends to describe the results of a review of videobased ice breaker materials designed by students who attended Games, Songs and Stories courses in the Department of Arabic Language Education, Faculty of Education and Teacher Training, Maulana Malik Ibrahim State Islamic University Malang. The student-produced ice breaker videos will be analyzed based on ice breaker material quality, video quality, and students' perception of the task of designing video-based ice breakers in the courses they participate in.

The purpose of this review is to show the wide variety of ice breakers in Arabic language learning, the quality of ice breaker-based videos directly designed by students as prospective professional teachers, and the importance of Games, Songs and Stories courses in the Arabic education curriculum because it contains material about ice breakers.

\section{METHOD}

This research method uses a mixture of qualitative and quantitative approaches in order to obtain more complete results. This research was conducted in the odd semester of the academic year 2020/2021 then in the Department of Arabic Language Education, Faculty of Education and Teacher Training, Maulana Malik Ibrahim State Islamic University Malang. Participants in this study were students who followed course Games, Songs and Stories. This course is the course of choice in the sixth semester. There are two classes; class A as many as 21 students and class B as many as 23 students. Of the 44 students enrolled, 40 ice breaker videos were obtained because 4 students did not collect ice breaker video making tasks. These 40 videos become objects to be analyzed. The focus of this 


\section{IJAZ ARAB I}

Journal of Arabic Learning

DOI: $10.18860 / \mathrm{ijazarabi.v4i3.13148}$

ISSN(print): $2620-5912$ | ISSN(online): $2620-5947$

ejournal.uin-malang.ac.id/index.php/ijazarabi/index

study is ice breaker videos produced by students for learning Arabic online and remotely.

The instruments used in this study were questionnaires, interviews, questionnaires, Google Forms, Google Drive, YouTube Channels, smartphones, WhatsApp. This instrument was chosen because it corresponds to the object of research and because of the pandemic situation that causes research to be conducted online. Researchers also status as instruments because researchers are involved in learning as lecturers. The research procedure begins with communication between researchers as lecturers, students and the Department of Arabic Language Education. Furthermore, researchers have the authority to access documents lecture and data related to the task of making ice breaker videos by students.

Assessment rubric used by lecturers in assessing the quality of ice breaker videos refers to table 1 . below:

Table 1. Ice Breaker Video Quality Assessment Rubric

\begin{tabular}{llllllll}
\hline No & Aspects of videoobserved & \multicolumn{3}{c}{ Scale } & & Note \\
\hline 1. & Video compatibility with theme & 1 & 2 & 3 & 4 & 5 & \\
\hline 2. & Completeness of captions in the form of & 1 & 2 & 3 & 4 & 5 & \\
\hline 3. & text & 1 & 2 & 3 & 4 & 5 & \\
\hline 4. & Audio quality & 1 & 2 & 3 & 4 & 5 & \\
\hline 5. & Articulation clarity & 1 & 2 & 3 & 4 & 5 & \\
\hline 6. & Lighting quality & 1 & 2 & 3 & 4 & 5 & \\
\hline 7. & Duration accuracy & 1 & 2 & 3 & 4 & 5 & \\
\hline 8. & Student appearance & 1 & 2 & 3 & 4 & 5 & \\
\hline
\end{tabular}

While the assessment rubric used by lecturers in assessing ice breaker material refers to table 2 below:

Table 2. Ice Breaker Video Quality Assessment Rubric

\begin{tabular}{llllllll}
\hline No & $\begin{array}{l}\text { Material aspects of ice breakers } \\
\text { assessed }\end{array}$ & \multicolumn{3}{c}{ Scale } & & \multirow{2}{*}{ Note } \\
\hline 1. & Ice Breaker Title and Theme & 1 & 2 & 3 & 4 & 5 & \\
\hline 2. & Types of Ice Breaker & 1 & 2 & 3 & 4 & 5 & \\
\hline 3. & Ice Breaker Destinations & 1 & 2 & 3 & 4 & 5 & \\
\hline 4. & Benefits of Ice Breaker & 1 & 2 & 3 & 4 & 5 & \\
\hline 5. & Ice Breaker Language & 1 & 2 & 3 & 4 & 5 & \\
\hline 6. & Material Interaction with Audiences & 1 & 2 & 3 & 4 & 5 &
\end{tabular}

The stage of data analysis begins by processing the data by means of transcription, video observing, reduction, video scoring and thematic classification. Then, the researchers presented the data through a table in accordance with the results of descriptive statistical calculations. Furthermore, researchers use qualitative content analysis techniques in interpreting data in order to obtain objective analysis results as verification material and answers to hypotheses. With this procedure, it can be known the quality of ice breaker videos designed by students from the aspect of video quality as well as from the material aspect of ice breaker so that the videos can be used for Arabic learning online and remotely. 
IJAZ ARAB I

Journal of Arabic Learning

DOI: $10.18860 / \mathrm{ijazarabi.v4i3.13148}$

ISSN(print): $2620-5912$ | ISSN(onIine): $2620-5947$

ejournal.uin-malang.ac.id/index.php/ijazarabi/index/5

\section{RESULTS AND DISCUSSION}

\section{Ice Breaker and Course Games, Songs And Stories}

In the Curriculum of Arabic Language Education there are courses called Games, Songs and Stories. This course is the course of choice in the sixth semester before students practice teaching in school in the seventh semester. Therefore, this course becomes a provision for students to improve their teaching skills because they are projected to be professional, skilled and innovative Arabic teachers. Ice breaker is one of the teaching materials delivered by lecturers in the lecture syllabus.

In the odd semester of the academic year 2020/2021, the number of students who chose the course Games, Songs and Stories as many as 44 out of 112 students, That means, as many as $39 \%$ of students choose this course. This number is the largest compared to the number of students who attend other elective courses, such as: journalism, Indonesian for foreigners, and multimedia.

In course Games, Songs and Stories, each student is given an independent assignment by the lecturer to be done outside the lecture session. One of the independent tasks that are individual and must be done by students is to design videos with ice breaker material. Out of 44 students, it is known that there are 40 ice breaker videos received by lecturers and have been assessed. There are 4 students who do not collect assignments because they do not manage to collect assignments at a set time. That means $90 \%$ of students successfully design ice breaker videos.

\section{Video Ice Breaker}

Videos designed by students are on average 2 to 3 minutes long. No more than 5 minutes. Each video must present: 1) introductory sessions in the form of: student identity, ice breaker title, purpose and benefits; 2) the main session in the form of ice breaker material delivered by students in detail and clearly according to the theme and type of ice breaker chosen;3) the closing session in the form of evaluation and greetings. In addition to the assignment in the form of a video, each student must also describe the content of the ice breaker in the form of a narrative typed with Microsoft Word. This ice breaker video description contains title, purpose, benefits, video-based ice breaker implementation techniques for Arabic language learning, video creation techniques, and references.

This assignment process is ordered by lecturers to students through the WhatsApp Group application as the main medium in communication between lecturers and students during online lectures. While the collection of assignments submitted by students through Google Forms which is then stored in the Google Drive account owned by the lecturer so that all tasks can be organized properly. After the assignment is assessed, the lecturer submits criticism and advice to students, then the lecturer uploads a video of ice breaker on the lecturer's YouTube account named taufiqnet with link: https://www.youtube.com/channel/UCtIIQf7NOTgNcq_P-i8dRdA 
From the questionnaires shared with students, it is known that the software used by students in designing ice breaker videos include: Microsoft PowerPoint, Kine Master, Viva Video, Video Shop, Filmora Go, PictArt, Snapseed, Canva, Super Sound, and Music Editor. While the hardware used by students is laptops and smartphones.

From the questionnaire collected, it is known that there are 40 out of 44 students who have done the task in the form of video ice breaker with details: 23 students $(57.5 \%)$ admitted very easy in putting together a video-based ice breaker, 15 students (37.5\%) admitted it is easy, 2 students (5\%) admitted ordinary, no students admitted difficult and very difficult in doing this task.



Image 1. Ice Breaker Task Difficulty Level

As for the feelings of students in doing the task of making this ice breaker video, it is known that there are 30 students (75\%) claim to be very happy, 8 students (20\%) claim to be happy, and 2 students (5\%) admitted to being ordinary. No student $(0 \%)$ claimed to be unhappy or very unhappy.



Image 2. Student's feelings in doing ice breaker assignments

The perception of 44 students about the urgency of using ice breaker videos for Arabic learning online and remotely, especially in the current pandemic era is that 35 students $(79.5 \%)$ claim to be very important, 6 students $(13.5 \%)$ claim to be important, 3 students (7\%) profess to be ordinary, and no students $(0 \%)$ who declare it not important or very not important. 
Journal of Arabic Learning

DOI: $10.18860 / \mathrm{ijazarabi.v4i3.13148}$

ISSN(print): 2620-5912 | ISSN(onIine): 2620-5947

ejournal.uin-malang.ac.id/index.php/ijazarabi/index

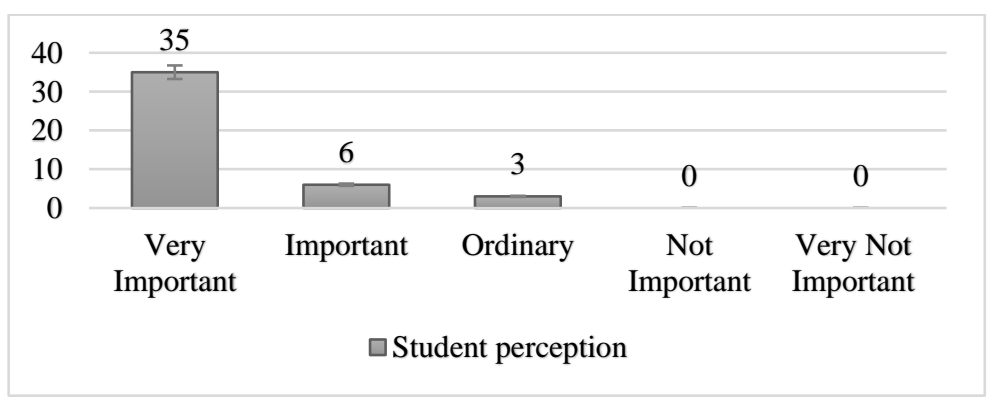

Image 3. Student perception of the urgency of ice breaker video

\section{Ice Breaker Video Types}

From the results of the lecturer's assessment of 40 ice breaker-based videos, it is known that the type of ice breaker video that contains 6 videos (15\%) applause, singing 10 videos (25\%), 22 video language games (55\%), 2 video quizzes (5\%). No ice breaker material in the form of storytelling, words of wisdom, language gymnastics, puzzles, and brain games.

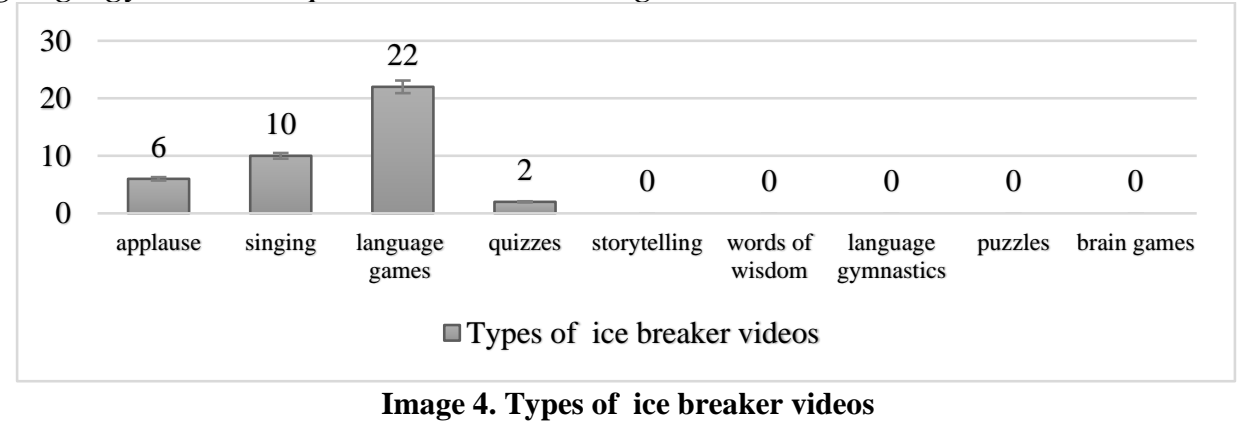

\section{Ice Breaker Video Rating Results}

The assessment of 40 student-produced ice breaker-based videos was divided into two; assessment of video quality and assessment of ice breaker material.

Table 3 below is the results of lecturers' assessment of video quality compiled by students based on the assessment rubric in table 1 .

Table 3. Video Quality Assessment Results

\begin{tabular}{clccclcc}
\hline & Student $(\mathbf{N})$ & Score & Letter & & Student $(\mathbf{N})$ & Score & Letter \\
\hline 1. & $\mathrm{~N}-1$ & 36 & $\mathrm{~A}$ & 21. & $\mathrm{~N}-21$ & 36 & $\mathrm{~A}$ \\
\hline 2. & $\mathrm{~N}-2$ & 38 & $\mathrm{~A}$ & 22. & $\mathrm{~N}-22$ & 35 & $\mathrm{~A}$ \\
\hline 3. & $\mathrm{~N}-3$ & 38 & $\mathrm{~A}$ & 23. & $\mathrm{~N}-23$ & 38 & $\mathrm{~A}$ \\
\hline 4. & $\mathrm{~N}-4$ & 39 & $\mathrm{~A}$ & 24. & $\mathrm{~N}-24$ & 32 & $\mathrm{~B}$ \\
\hline 5. & $\mathrm{~N}-5$ & 33 & $\mathrm{~A}$ & 25. & $\mathrm{~N}-25$ & 31 & $\mathrm{~B}$ \\
\hline 6. & $\mathrm{~N}-6$ & 30 & $\mathrm{~B}$ & 26. & $\mathrm{~N}-26$ & 37 & $\mathrm{~A}$ \\
\hline 7. & $\mathrm{~N}-7$ & 36 & $\mathrm{~A}$ & 27. & $\mathrm{~N}-27$ & 38 & $\mathrm{~A}$ \\
\hline 8. & $\mathrm{~N}-8$ & 31 & $\mathrm{~B}$ & 28. & $\mathrm{~N}-28$ & 39 & $\mathrm{~A}$ \\
\hline 9. & $\mathrm{~N}-9$ & 36 & $\mathrm{~A}$ & 29. & $\mathrm{~N}-29$ & 39 & $\mathrm{~A}$ \\
\hline 10. & $\mathrm{~N}-10$ & 31 & $\mathrm{~B}$ & 30. & $\mathrm{~N}-30$ & 36 & $\mathrm{~A}$ \\
\hline 11. & $\mathrm{~N}-11$ & 34 & $\mathrm{~A}$ & 31. & $\mathrm{~N}-31$ & 34 & $\mathrm{~A}$ \\
\hline 12. & $\mathrm{~N}-12$ & 38 & $\mathrm{~A}$ & 32. & $\mathrm{~N}-32$ & 35 & $\mathrm{~A}$ \\
\hline
\end{tabular}




\section{IJAZ ARAB I}

Journal of Arabic Learning

DOI: $10.18860 / \mathrm{ijazarabi.v4i3.13148}$

ISSN(print): $2620-5912$ | ISSN(onIine): $2620-5947$

ejournal.uin-malang.ac.id/index.php/ijazarabi/index

\begin{tabular}{llllllll}
\hline 13. & $\mathrm{N}-13$ & 32 & $\mathrm{~B}$ & 33. & $\mathrm{~N}-33$ & 32 & $\mathrm{~B}$ \\
\hline 14. & $\mathrm{~N}-14$ & 37 & $\mathrm{~A}$ & 34. & $\mathrm{~N}-34$ & 37 & $\mathrm{~A}$ \\
\hline 15. & $\mathrm{~N}-15$ & 38 & $\mathrm{~A}$ & 35. & $\mathrm{~N}-35$ & 32 & $\mathrm{~B}$ \\
\hline 16. & $\mathrm{~N}-16$ & 35 & $\mathrm{~A}$ & 36. & $\mathrm{~N}-36$ & 37 & $\mathrm{~A}$ \\
\hline 17. & $\mathrm{~N}-17$ & 35 & $\mathrm{~A}$ & 37. & $\mathrm{~N}-37$ & 34 & $\mathrm{~A}$ \\
\hline 18. & $\mathrm{~N}-18$ & 37 & $\mathrm{~A}$ & 38. & $\mathrm{~N}-38$ & 35 & $\mathrm{~A}$ \\
\hline 19. & $\mathrm{~N}-19$ & 37 & $\mathrm{~A}$ & 39. & $\mathrm{~N}-39$ & 36 & $\mathrm{~A}$ \\
\hline 20. & $\mathrm{~N}-20$ & 34 & $\mathrm{~A}$ & 40. & $\mathrm{~N}-40$ & 34 & $\mathrm{~A}$ \\
\hline
\end{tabular}

Based on table 3 above, it is known that the lowest score of the studentproduced video score is 30 and the highest score is 39 . The average value of video quality is 35.3000 with a standard deviation of 2.51355 and variant 6.318 . The following are the results of descriptive analysis using IBM SPSS Statistics software.

Table 4. Descriptive Analysis of Ice Breaker Video Quality Values

\begin{tabular}{lcccccc}
\hline & N & Minimum & Maximum & Mean & Std. Deviation & Variance \\
\hline Scores & 40 & 30.00 & 39.00 & 35.3000 & 2.51355 & 6.318 \\
\hline $\begin{array}{l}\text { Valid N } \\
\text { (listwise) }\end{array}$ & 40 & & & & & \\
\hline
\end{tabular}

While the lecturer's assessment of the content or material ice breaker in the video designed by students, based on the assessment rubric in table 2 is as follows.

Table 5. Descriptive Analysis of Ice Breaker Video Quality Values

\begin{tabular}{|c|c|c|c|c|c|c|c|}
\hline & Student (N) & Score & Letter & & Student (N) & Score & Letter \\
\hline 1. & $\mathrm{~N}-1$ & 29 & A & 21. & $\mathrm{~N}-21$ & 26 & A \\
\hline 2. & $\mathrm{~N}-2$ & 28 & $\mathrm{~A}$ & 22. & $\mathrm{~N}-22$ & 25 & A \\
\hline 3. & $\mathrm{~N}-3$ & 29 & A & 23. & $\mathrm{~N}-23$ & 28 & A \\
\hline 4. & $\mathrm{~N}-4$ & 30 & A & 24. & $\mathrm{~N}-24$ & 23 & $\mathrm{~B}$ \\
\hline 5. & $\mathrm{~N}-5$ & 23 & B & 25. & $\mathrm{~N}-25$ & 21 & B \\
\hline 6. & $\mathrm{~N}-6$ & 21 & $\mathrm{~B}$ & 26. & $\mathrm{~N}-26$ & 26 & A \\
\hline 7. & $\mathrm{~N}-7$ & 28 & A & 27. & $\mathrm{~N}-27$ & 29 & A \\
\hline 8. & $\mathrm{~N}-8$ & 22 & $\mathrm{~B}$ & 28. & $\mathrm{~N}-28$ & 30 & A \\
\hline 9. & $\mathrm{~N}-9$ & 26 & A & 29. & $\mathrm{~N}-29$ & 29 & A \\
\hline 10. & $\mathrm{~N}-10$ & 20 & B & 30. & $\mathrm{~N}-30$ & 28 & A \\
\hline 11. & $\mathrm{~N}-11$ & 22 & $\mathrm{~B}$ & 31. & $\mathrm{~N}-31$ & 26 & A \\
\hline 12. & $\mathrm{~N}-12$ & 28 & $\mathrm{~A}$ & 32. & $\mathrm{~N}-32$ & 25 & A \\
\hline 13. & $\mathrm{~N}-13$ & 24 & B & 33. & $\mathrm{~N}-33$ & 22 & B \\
\hline 14. & $\mathrm{~N}-14$ & 26 & A & 34. & $\mathrm{~N}-34$ & 27 & A \\
\hline & $\mathrm{N}-15$ & 29 & A & 35. & $\mathrm{~N}-35$ & 22 & B \\
\hline 16. & $\mathrm{~N}-16$ & 27 & A & 36. & N-36 & 30 & A \\
\hline 17. & N-17 & 27 & A & 37. & N-37 & 22 & B \\
\hline 18. & N-18 & 28 & A & 38. & N-38 & 24 & B \\
\hline 19. & $\mathrm{~N}-19$ & 28 & A & 39. & N-39 & 26 & A \\
\hline 20. & $\mathrm{~N}-20$ & 23 & B & 40. & $\mathrm{~N}-40$ & 24 & B \\
\hline
\end{tabular}

From table 5 above, it is known that the lowest score of the score on ice breaker material in the student-produced video is 20 and the highest score is 30 . The average value of video quality is 25.7750 with a standard deviation of 2.90435 and variant 8.435 . Here are the results of descriptive analysis using IBM SPSS Statistics software. 


\section{IJAZ ARAB I}

Journal of Arabic Learning

DOI: $10.18860 / \mathrm{ijazarabi.v4i3.13148}$

ISSN(print): $2620-5912$ | ISSN(online): $2620-5947$

ejournal.uin-malang.ac.id/index.php/ijazarabi/index $\mathbf{5 6 5}$

Table 6. Descriptive Analysis of Ice Breaker Materials

\begin{tabular}{lcccccc}
\hline & N & Minimum & Maximum & Mean & Std. Deviation & Variance \\
\hline Scores & 40 & 20.00 & 30.00 & 25.7750 & 2.90435 & 8.435 \\
\hline $\begin{array}{l}\text { Valid N } \\
\text { (listwise) }\end{array}$ & 40 & & & & & \\
\hline
\end{tabular}

While the final score obtained by students after attending the course Games, Songs and Stories are as follows.

Table 7. Student Scores on Ice Breaker Videos

\begin{tabular}{cccccccc}
\hline No & Value Range & $\begin{array}{c}\text { Letter } \\
\text { Value }\end{array}$ & $\begin{array}{c}\text { Number } \\
\text { Value }\end{array}$ & Class A & Class B & Sum & $\%$ \\
\hline $\mathbf{1}$ & $85-100$ & A & 4 & 10 & 14 & 24 & 55 \\
\hline $\mathbf{2}$ & $70-74$ & B & 3 & 7 & 6 & 13 & 30 \\
\hline $\mathbf{3}$ & $60-69$ & C & 2 & 2 & 1 & 3 & 7 \\
\hline $\mathbf{4}$ & $50-59$ & D & 1 & 2 & 2 & 4 & 9 \\
\hline $\mathbf{5}$ & $<50$ & E & 0 & 0 & 0 & 0 & 0 \\
\hline & & & & $\mathbf{2 1}$ & $\mathbf{2 3}$ & $\mathbf{4 4}$ & $\mathbf{1 0 0}$ \\
\hline
\end{tabular}

Table 7. above shows that 24 students (55\%) get A (very good), 13 students (30\%) B grades (good), 3 students (7\%) C grades (enough), 4 students (9\%) D grades (less) because they do not do tasks in the form of video ice breakers, and no students get an E (failed).

\section{DISCUSSION}

\section{Ice Breaker Urgency for Arabic Learning}

Based on the data shown, it is known that ice breaker material is indispensable in the learning process, including Arabic language learning. This is because ice breakers are useful to increase students' motivation, eliminate boredom, make students fresh and feel happy to learn. This benefit is necessary in the online learning process which causes students to feel saturated and less motivated. In addition, in some Arabic courses, it has been known to be difficult such as nahwu (grammar), sharaf (morphology), balaghah (rhetoric), and so on. If this teaching material is delivered monotonously and not interspersed with ice breakers, then students will increasingly find it difficult and lackluster. Therefore, ice breaker material becomes very important according to the perception of students that 35 students $(79.5 \%)$ claim to be very important, 6 students $(13.5 \%)$ claim to be important (see table 5.).

Not only that, in the Arabic language learning curriculum must be ensured that there are courses that contain about ice breakers. The Curriculum of Arabic language education in the Department of Arabic Language Education, Faculty of Education and Teacher Training, Maulana Malik Ibrahim State Islamic University Malang, has accommodated material about ice breakers in the syllabus of Games, Songs and Stories courses. According to the researchers, this finding is very interesting because the researchers did not find any courses games, songs and stories in the Arabic curriculum in general. That means, the curriculum in the Department of Arabic Language Education has been in accordance with the needs 
and able to overcome the problems of Arabic language learning that students feel such as lack of motivation and low achievement.

The existence of Games, Songs and Stories courses in the Department of Arabic Language Education, turned out to be the favorite course chosen by most students. With this course, they felt given the opportunity to develop ideas and hone their creativity in devising innovative Arabic learning strategies, including designing ice breaker-based videos. Evidently, $90 \%$ of students are able to design video-based ice breakers in a short period of time. In fact, they were pleased with the task of the lecturer to compose the ice breaker video. They are also happy because their work in the form of ice breaker videos has been uploaded on the internet so it is useful for many people.

\section{Ice Breaker Videos and Online Learning}

Online learning requires hardware and software. Video is part of the multimedia element needed in electronic-based learning for online and remote learning. Today is the era of Massive Open Online Course (MOOC) (Milligan \& Littlejohn, 2017). This era is, among others, marked by changes in paradigm learning along with the rapid flow of information on the internet coming from various sources (Knox, 2017) (Febiharsa \& Kustono, 2021). From the internet, people or students can find a variety of positive content such as e-lessons, e-books, e-disses, and so on. Therefore, in this era of MOOC, teachers and students must participate in filling in positive learning content in cyberspace and that can benefit many people. Therefore, the task of lecturers to students to be able to design ice breaker-based videos is part of efforts to produce as much video-based teaching materials and encourage students to be creative. The task of producing this ice breaker material, it can be done independently by students very easily. Lecturers only act as facilitator by giving assignments, reviewing and conveying feedback to students (Masek, 2019).

Ice breaker practices have often been done offline because teachers and students or tutors and audiences can interact directly, actively and effectively. While the practice of ice breaker online, has not been done much so the content about ice breaker for Arabic learning is still a little. From the results of this research, it is known that student production in the form of 40 ice breaker videos has contributed in enriching and adding video and digital-based ice breaker content that can be accessed through internet. In this way, it means that students in the Department of Arabic Language Education have contributed actively to present digital materials in the MOOC era.

\section{Students' Ability to Design Ice Breaker Videos}

Based on the exposure of data in tables 3, 4, 5, 6, 7, it is known that students are able to produce ice breaker-based videos with excellent ice breaker video quality and content. They as prospective professional teachers proved able to make interactive ice breaker videos according to the theme, purpose and benefits of ice 
Journal of Arabic Learning

DOI: $10.18860 / \mathrm{ijazarabi.v4i3.13148}$

ISSN(print): $2620-5912$ | ISSN(onIine): $2620-5947$

ejournal.uin-malang.ac.id/index.php/ijazarabi/index

breaker. They are also capable of producing quality videos from aspects of image composition, audio, video, text, duration, performance, and so on according to good video standards and worth watching.

From the aspect of the type of ice breaker contained in the video produced by students, researchers found that they only present the type of ice breaker in the form of applause, singing, language games and quizzes. No student has yet presented ice breaker-based videos with other types such as storytelling, words of wisdom, language gymnastics, puzzles, and brain gymnastics. Researchers believe that this is not because students are unable to design these types of ice breakers, but they are limited by rules about video length that should not exceed 5 minutes. Of course, to design an ice breaker such as language gymnastics or brain gymnastics takes about 10 to 15 minutes.

Based on the value of video quality and the value of ice breaker material, researchers know that students have been able to produce ice breaker-based videos very well. They already have the necessary video and digital-based teaching material design skills in the era of online and remote learning. This success is thanks to the Arabic curriculum that accommodates new courses needed in the MOOC era and society 5.0 era.

\section{CONCLUSION}

Ice breaker-based video is a necessary product in online and remote learning. This video should be widely produced by students as prospective professional teachers in the era of MOOC and Society 5.0. This need has been accommodated by the Arabic curriculum in the Department of Arabic Language Education with the courses Games, Songs, and Stories. Through this lecture material, students are able to produce ice breaker-based videos to overcome learning problems such as low motivation of students, the emergence of saturated feelings, and the lack of learning video materials that contain ice breakers for Arabic language learning.

This research shows that students are able to produce ice breaker videos with video quality and ice breaker material quality well. This activity shows that students as millennials are able to create, while lecturers succeed in encouraging the growth of student interests and talents. The types of ice breakers contained in the studentdesigned videos are applause, singing, language games and quizzes. While the types of ice breakers such as storytelling, words of wisdom, language gymnastics, puzzles, and brain gymnastics, have not appeared in the ice breaker-based videos produced by students. Therefore, they need to be trained more intensively and given the opportunity to compose longer-duration videos so that they can explore creative and innovative ideas better.

\section{REFERENCES}

Amalia, A. (2020). Ice Breaking dalam Pembelajaran Bahasa Arab. Shaut al Arabiyyah, 8(1), 75-85. https://doi.org/10.24252/saa.v8i1.11551 
IJAZ ARABI

Journal of Arabic Learning

DOI: $10.18860 / \mathrm{ijazarabi.v4i3.13148}$

ISSN(print): 2620-5912 | ISSN(onIine): 2620-5947

ejournal.uin-malang.ac.id/index.php/ijazarabi/index/ 568

Ariadhy, S. Y., Nurohman, S., Arkum, D., Handini, W., \& Ferdiana, F. (2020). Pelatihan Pembelajaran Jarak Jauh di Era Pandemi Covid-19. Anoa: Jurnal Pengabdian Masyarakat Sosial, Politik, Budaya, Hukum, Ekonomi, 1(3), 220-226. https://doi.org/10.52423/anoa.v1i3.13640

Aziz, F. (2019). Pengaruh Permainan Ice Breaker dalam Meningkatkan Hasil Belajar Siswa Mata Pelajaran PAI Kelas VII SMP Negeri 5 Kota Bengkulu (Diploma, IAIN Bengkulu). IAIN Bengkulu, Bengkulu. Retrieved from http://repository.iainbengkulu.ac.id/3606/

Azzahra, N. F. (2020). Mengkaji Hambatan Pembelajaran Jarak Jauh di Indonesia di Masa Pandemi Covid-19. https://doi.org/10.35497/309163

Bevan, M. (2020). Why Videos are Important in Education. Retrieved 8 August 2021, from https://www.nextthoughtstudios.com/video-productionblog/2017/1/31/why-videos-are-important-in-education

Cahyani, A., Listiana, I. D., \& Larasati, S. P. D. (2020). Motivasi Belajar Siswa SMA pada Pembelajaran Daring di Masa Pandemi Covid-19. IQ (Ilmu Al-Qur'an): Jurnal Pendidikan Islam, 3(01), 123-140. https://doi.org/10.37542/iq.v3i01.57

Devi, V. C., Muncarno, M., \& H, Y. (2019). Pengaruh Ice Breaker Jenis Games terhadap Hasil Belajar Tematik. Pedagogi: Jurnal Pendidikan Dasar, 7(3). $\quad$ Retrieved from http://jurnal.fkip.unila.ac.id/index.php/pgsd/article/view/18186

Fadhal, S. (2020). Hambatan Komunikasi dan Budaya dalam Pembelajaran Daring pada Masa Pandemi COVID-19. In Kolaborasi lawan (hoaks) COVID-19: Kampanye, riset dan pengalaman Japelidi di tengah pandemi (pp. 273-290). Yogyakarta: Program Studi Magister Ilmu Komunikasi UGM. Retrieved from https://eprints.uai.ac.id/1539/1/ILS0001-21_Isi-Artikel.pdf

Fahruni, F. E., \& Warsito, H. (2021). Analisis Faktor-Faktor Penyebab Perilaku Malas Belajar Daring saat Pandemi Covid-19 pada Siswa Kelas XII SMA Negeri 1 Menganti Gresik. Jurnal BK UNESA, 12(2). Retrieved from https://jurnalmahasiswa.unesa.ac.id/index.php/jurnal-bkunesa/article/view/36431

Febiharsa, D., \& Kustono, D. (2021). Kajian Filosofis Pembelajaran Daring Pendidikan Vokasi di Era Pandemi COVID-19: Analisis Fungsional Sarana Pembelajaran Daring Terhadap Esensi Pembelajaran. https://doi.org/10.31331/joined.v4i1.1530

Heathfield, S. M. (2020). What Is an Icebreaker? Retrieved 8 August 2021, from The Balance Careers website: https://www.thebalancecareers.com/what-is-an-ice-breaker-1918156

Hutasoit, R., \& Tambunan, Drs. B. (2018). The Effect of Ice Breaking Technique in Teaching Speaking at the Tenth Grade Students of SMK Dharma Bhakti Siborongborong in Academic Year 2018/2019. International 
IJAZ ARAB I

Journal of Arabic Learning

DOI: $10.18860 / \mathrm{ijazarabi.v4i3.13148}$

ISSN(print): 2620-5912 | ISSN(onIine): 2620-5947

ejournal.uin-malang.ac.id/index.php/ijazarabi/index/569

Journal of English Literature and Social Sciences, 3(5), 700-705. https://doi.org/10.22161/ijels.3.5.2

Khoirullah, A. (2020). Pengaruh Penggunaan Teknik Ice Breaker dalam Pembelajaran terhadap Motivasi Belajar Siswa Kelas V SDN Cihampelas (Other, FKIP UNPAS). FKIP UNPAS. https://doi.org/10/16.\%20BAB\%20V.pdf

Knox, J. (2017). How goes the revolution? Three themes in the shifting MOOC landscape. Educação e Tecnologia: Abordagens Criticas, 24.

Masek, A. (2019). Mode and Dimension of Facilitation in Student-Centred Learning Approach: A Comparison of Teaching Experience. International Journal of Active Learning, 4(1), 24-32.

Milligan, C., \& Littlejohn, A. (2017). Why Study on a MOOC? The Motives of Students and Professionals. International Review of Research in Open and Distributed Learning, 18(2), 92-102. https://doi.org/10.19173/irrodl.v18i2.3033

Puteri, W. A., Maharani, D. A., \& Wulandari, A. (2020). Penggunaan Media Audio Visual untuk Meningkatkan Motivasi Belajar Siswa selama Masa Pandemi Covid-19 pada SDN 1 Serayu Larangan. ABDIPRAJA (Jurnal Pengabdian Kepada Masyarakat), 1(1), 122-129. https://doi.org/10.31002/abdipraja.v1i1.3146

Putri, D. D. (2020). Pengaruh Ice Breaker terhadap Hasil Belajar IPA Peserta Didik Kelas IV SD Negeri 15 Salolo Kota Palopo (Skripsi, Universitas Cokroaminoto Palopo). Universitas Cokroaminoto Palopo. Retrieved from http://repository.uncp.ac.id/565/

Rachmadtullah, R., Yustitia, V., Setiawan, B., Fanny, M., Pramulia, P., Susiloningsih, W., ... Ardhian, T. (2020). The Challenge Of Elementary School Teachers To Encounter Superior Generation In The 4.0 Industrial Revolution: Study Literature. International Journal of Scientific \& Technology Research, 9, 1879-1882.

Rifnida, R., Abdulloh, A., \& Helili, E. (2021). Pengaruh Pembelajaran Daring terhadap Minat Belajar Siswa pada Masa Covid-19. Lentera: Jurnal Ilmiah Kependidikan, 14(1), 63-72. https://doi.org/10.52217/lentera.v14i1.784

Solihat, A., Astuti, A. R., \& Satriani, I. (2020). The Influence of Ice Breaker to Students' Motivation in Teaching English. PROJECT (Professional Journal of English Education), 3(2), 210. https://doi.org/10.22460/project.v3i2.p210-216 